\title{
Рарег
}

\section{Opinions of veterinarians on antimicrobial use in farm animals in Flanders and the Netherlands}

\author{
M. Postma, D. C. Speksnijder, A. D. C. Jaarsma, T. J. M. Verheij, J. A. Wagenaar, J. Dewulf
}

\begin{abstract}
Veterinarians play an important role in the reduction of antimicrobial use in farm animals. This study aims to quantify opinions of veterinarians from the Netherlands and Flanders regarding antimicrobial use and resistance issues in farm animals. An online survey was sent out to 678 and 1100 farm animal veterinarians in Flanders and the Netherlands, of which 174 and 437 were returned respectively. Suboptimal climate conditions were regarded as the most important cause for high antimicrobial use in farm animals. Flemish veterinarians also regarded insufficient biosecurity measures and farmers' mentality as important determinants, while the Dutch respondents ranked insufficient immunity of young animals and economic considerations of farmers as major causes. The majority of Dutch respondents (63.8 per cent) supported the existing national policy, which aimed to halve veterinary antimicrobial use, while the Flemish (32.9 per cent) were less supportive of such a policy. Improvements in housing and climate conditions, biosecurity measures and strict control of specific infectious diseases were seen as important and promising measures to reduce antimicrobial use. To reduce antimicrobial use in farm animals, some shared approaches might be applicable in both countries. However, cultural, political and societal differences between Flanders and the Netherlands require differentiated approaches to reduce veterinary antimicrobial use.
\end{abstract}

There is a strong global movement towards a reduction of antimicrobial use (AMU) in humans and animals to limit the increasing burden of antimicrobial resistance (AMR) (McEwen 2006, Aarestrup and others 2008, Prescott 2008, Collignon and others 2009). The majority of veterinary antimicrobials are used

\section{Veterinary Record (2016)}

M. Postma, DVM, PhD, J. Dewulf, DVM, PhD, DipECVPH, Veterinary Epidemiology Unit, Department of Reproduction, Obstetrics and Herd Health, Faculty of Veterinary Medicine, Ghent University, Merelbeke, Belgium

D. C. Speksnijder, DVM,

J. A. Wagenaar, DVM, PhD, DipECVPH,

Department of Infectious Diseases \& Immunology, Faculty of Veterinary Medicine, Utrecht University, Utrecht, The Netherlands

Veterinary Clinic Tweestromenland, Wijchen, The Netherlands

A. D. C. Jaarsma, DVM, PhD,

Center for Research and Innovation in Medical Education, University Medical Center, Groningen, The Netherlands T. J. M. Verheij, MD, PhD,

Julius Center for Health Sciences and doi: 10.1136/vr.103618

Primary Care, University Medical Center, Utrecht, The Netherlands Central Veterinary Institute (CVI) of Wageningen UR, Lelystad,

The Netherlands

D. C. Speksnijder is also at Veterinary Clinic Tweestromenland, Wijchen, The Netherlands

J. A. Wagenaar is also at Central Veterinary Institute (CVI) of Wageningen UR, Lelystad, The Netherlands

E-mail for correspondence: Merel.Postma@ugent.be

M. Postma and D.C. Speksnijder share the first authorshop of this manuscript.

Provenance: Not commissioned; externally peer reviewed

Accepted May 3, 2016 in food-producing animals. Veterinarians are usually responsible for prescribing and overseeing the use of these antimicrobials (Morley and others 2005, Van Boeckel and others 2015). Thus, addressing prescribing behaviour of farm animal veterinarians can be important to limit the evolving threat of AMR. However, so far only a few papers have discussed determinants that drive antimicrobial prescribing behaviour of farm animal veterinarians and to which extent cultures and existing policies influence these attitudes (De Briyne and others 2013, Gibbons and others 2013)

More is known about prescribing decisions of physicians that are generally influenced by a wide range of factors related to personal attitudes, knowledge, existing policies and patient influences, but also to more implicit influences like cultural dimensions. Studies comparing antimicrobial prescribing behaviour and risk-taking attitudes of general practitioners in Flanders and the Netherlands have shown different levels of outpatient $\mathrm{AMU}$, which are partly related to cultural and policy differences (Grol and others 1990, Coenen and others 2004, 2009, Deschepper and others 2008).

Farming practices are quite comparable in Flanders (Dutch-speaking northern part of Belgium comprising 60 per cent of the inhabitants) and the Netherlands (EUROSTAT 2015). In 2009, veterinary AMU in Belgium and the Netherlands was at a similar level (ESVAC 2012). In 2010, the Dutch government introduced a strict compulsory policy to reduce veterinary AMU in farm animals by 50 per cent in 2013 compared with 2009 and later formulated the ambition for a 70 per cent reduction in 2015 (Speksnijder and others 2015c). Through several mandatory interventions (Speksnijder and others 2015c), the 
Dutch livestock sectors accomplished a 56 per cent reduction in 2013 with a levelling in 2014 (58 per cent) compared with 2009 (Van Geijlswijk and others 2015). In Belgium, the Center of Expertise on Antimicrobial Consumption and Resistance in Animals (AMCRA 2014a) was established in 2012, supported by both the government and the involved stakeholders (veterinary and agricultural organisations, feed and pharmaceutical companies, universities). The Center of Expertise on Antimicrobial Consumption and Resistance in Animals (AMCRA) attempts to reduce the AMU through advice and awareness raising of farmers, veterinarians and the public. A reduction in veterinary AMU of around 13 per cent between 2011 and 2013 and a subsequent slight increase of 1.3 per cent in 2014 was seen (Dewulf and others 2014, 2015).

The aim of this study was (1) to describe the different opinions and behaviours regarding veterinary AMU in the Dutch and Flemish population of farm animal veterinarians during the first years of diverging veterinary antimicrobial policies between the two countries and (2) to assess the perceived effectiveness of several measures for reduction of AMU in the different countries. The outcomes of this study might improve the understanding of farm animal veterinarians in their antimicrobial prescribing behaviour in different countries and can guide different approaches aiming at improving judicious use of antimicrobials in different regions.

\section{Materials and methods Questionnaire}

Differences in beliefs of Dutch veterinarians related to veterinary AMU and antimicrobial reduction were previously identified using qualitative methods (Speksnijder and others 2015a). These results were used to generate a theoretical framework, which in turn was used to develop a questionnaire that is described in detail in Speksnijder and others (2015b) and available upon request.

The questionnaire consisted of general descriptives, five-point Likert scale statements assessing the support of respondents to given statements and ranking questions assessing opinions of veterinarians regarding antibiotic use and reduction measures in farm animals as well as their perceived role in and control over reduction of AMU. The questionnaire was developed in a collaboration of a group of veterinary and medical experts and pilot tested among veterinarians working at the Veterinary Faculty of Utrecht University.

Respondents were eligible for participation if they worked at least one day a week with farm animals. In the Netherlands, based on a database provided by the Royal Dutch Veterinary Association, virtually all practising farm animal veterinarians were invited by email to fill in the questionnaire. Reminders were send after two and seven weeks and a $€ 20$ incentive was provided for every completed questionnaire (for further details, see Speksnijder and others 2015b). In Flanders, the original Dutch questionnaire had been slightly adjusted to fit the Flemish situation. Questions specifically designed based on the then existing Dutch policy were rephrased to questions asking whether Flemish veterinarians would support similar policy measures in Flanders.

In Flanders, all farm animal veterinarians that were registered in the email database of the institute for post-academic veterinary education (IPV Diergeneeskunde) at Ghent University received an invitation to participate in this online survey $(\mathrm{N}=678)$. The first request was sent in June 2012. A first reminder was sent 10 days later. A final reminder was sent four weeks later. The response was collected anonymously, unless contact details for future research were left voluntarily. Among responders that completed the questionnaire, ten $€ 20$ vouchers were raffled as a reward. Both surveys were distributed online through SurveyMonkey (SurveyMonkey.com, Palo Alto, California, USA)

\section{Analysis}

Analyses of all the data from both countries were performed using SPSS version 21 (IBM Corp. 2011). Descriptive distribution statistics of responses on the Likert scales were provided. Diverging stacked bar charts were created using Tableau 8.2 (Tableau Software, Seattle, Washington DC, USA). The nonparametric Mann-Whitney test was used for statistical analysis of the ordinal Likert-type data to assess differences in frequency distribution between respondents from the two countries. $P$ values $<0.05$ were considered significant. For binary outcomes (type of affiliation, working with several animal species; yes/no), $\chi^{2}$ testing was used to compare respondents. To compare perceived achievable antimicrobial reduction estimates, the independent $t$ test was used. Missing data were addressed as such.

\section{Results}

Survey response and respondents' characteristics

After removal of respondents who did not fulfil the selection criterion of working at least one day a week with farm animals, the authors received 174 (of which 50 were incomplete) questionnaires from Flemish participants. In the Netherlands, the authors received 437 (60 incomplete) questionnaires, resulting in a response rate of 26 per cent for Flanders and 40 per cent for the Netherlands, respectively, based on the number of questionnaires sent in Flanders (678) and the estimated population size of around 1.100 farm animal veterinarians in the Netherlands in 2012. Characteristics of the respondents are shown in Table 1. A (non-significant) tendency was visible that Flemish respondents were more frequently practice owners compared with their Dutch colleagues $(\mathrm{P}=0.06)$. Flemish respondents reported to devote more of their working time to pigs $(\mathrm{P}<0.01)$ and cattle $(\mathrm{P}<0.01)$ compared with the Dutch respondents. For the other farm animal species, there were no significant differences between the respondents from the two countries.

\section{Perceived causes of high AMU in farm animals}

The perceived importance of several possible causes for AMU in farm animals was tested in the questionnaire. Respondents from both countries equally believed that suboptimal climate conditions in the stables were one of the most important causes of high AMU (Fig 1). Flemish veterinarians had a strong opinion that insufficient biosecurity measures and the mentality of farmers to easily use antimicrobials were very important causes of high AMU in animals.

Dutch respondents considered the generally insufficient immunity of young farm animals and economic considerations of farmers as the most important causes of high veterinary AMU, which significantly differed from their Flemish colleagues. Views differed markedly on feed quality as a cause for high AMU. Less than a quarter of the Flemish respondents regarded

\begin{tabular}{|c|c|c|}
\hline & $\begin{array}{c}\text { Flanders } \\
(n=118)\end{array}$ & $\begin{array}{l}\text { The Netherlands } \\
\qquad(n=377)\end{array}$ \\
\hline Mean years in practice $(95 \% \mathrm{Cl})$ & $\begin{array}{l}16.4 \text { (14.5 to } \\
18.4)\end{array}$ & 15.8 (14.8 to 16.8$)$ \\
\hline Proportion practice owners* & $72.6 \%$ & $62.9 \%$ \\
\hline $\begin{array}{l}\text { Devoted time to different animal } \\
\text { species }\end{array}$ & $\begin{array}{l}\text { Flanders } \\
(n=168)\end{array}$ & $\begin{array}{l}\text { The Netherlands } \\
(\mathrm{n}=437)\end{array}$ \\
\hline$>20 \%$ poultry & $6.2 \%$ & $9.8 \%$ \\
\hline$>20$ swine & $51.9 \%$ & $35.9 \%$ \\
\hline$>20 \%$ cattle & $93.0 \%$ & $85.2 \%$ \\
\hline$>20 \%$ veal calves & $26.3 \%$ & $16.3 \%$ \\
\hline
\end{tabular}


Question

Climate in stables is suboptimal, leading to espiratory problems requiring antibiotics

Infectious diseases easily spread because

considered ${ }^{*}$

For economic reasons, farmers treat sick

(implementin

measures $^{\star \star}$

The immunity of the supplied animals is

suboplimal, making them susceptible for

infectious diseases

Antibiotic treatments are often economically

beneficial to treat moderate clinica
and are there fore quickly applied

The mentality of farmers is to prefer antibiotic reatment instead of accepting small production losses or mortality rates"

General management of farmers fails,leading to infectious diseases

The very proper registration in the Netherlands/Belgium makes veterinary antibiotic consumption seemingly higher than abroad ${ }^{\star *}$

The aim for maximum growth or production make animals sensitive for infections

Feed quality is suboptimal, leading to digestive disorders requiring antibiotics"

Financial benefits for veterinarians after

Country

Flanders

Netherlands

Flanders

Netherlands

Flanders

Netherlands

Flanders

Netherlands

Flanders

Netherlands

Flanders

Netherlands

Flanders

Netherlands

Flanders

Netherlands

Flanders

Netherlands

Flanders

Netherlands

Flanders

Netherlands

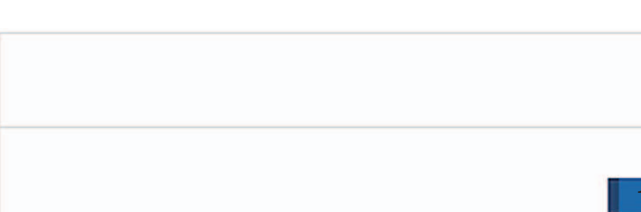

$\Gamma$

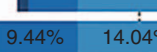

\begin{tabular}{|l|l|}
\hline $8.22 \%$ & $11.64 \%$
\end{tabular}

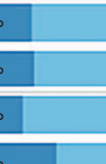

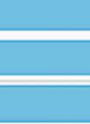

$54.58 \%$

$50.00 \%$

$43.45 \%$

$\quad 24.27 \%$

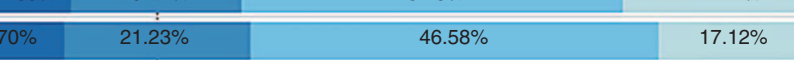

\begin{tabular}{|l|l|l|}
\hline $14.04 \%$ & $54.00 \%$ & $23.73 \%$ \\
\hline
\end{tabular}

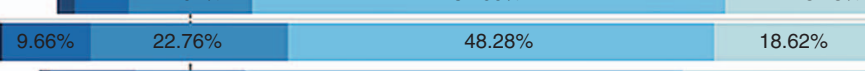

\begin{tabular}{|l|c|c|}
\hline $9.69 \%$ & $12.35 \%$ & $49.88 \%$ \\
\hline
\end{tabular}

\begin{tabular}{|l|l}
\hline $.81 \%$ & $23.61 \%$ \\
\hline
\end{tabular}

\begin{tabular}{l|r|}
$53.51 \%$ & $16.67 \%$ \\
\hline
\end{tabular}

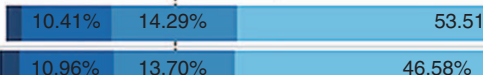

$43.10 \%$

$43.10 \%$

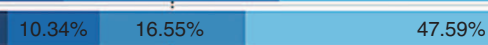

\begin{tabular}{|c|c|r|r|}
\hline $10.34 \%$ & $16.55 \%$ & $47.59 \%$ & $22.07 \%$ \\
\hline $27.18 \%$ & $41.99 \%$ & $11.17 \%$ \\
\hline
\end{tabular}

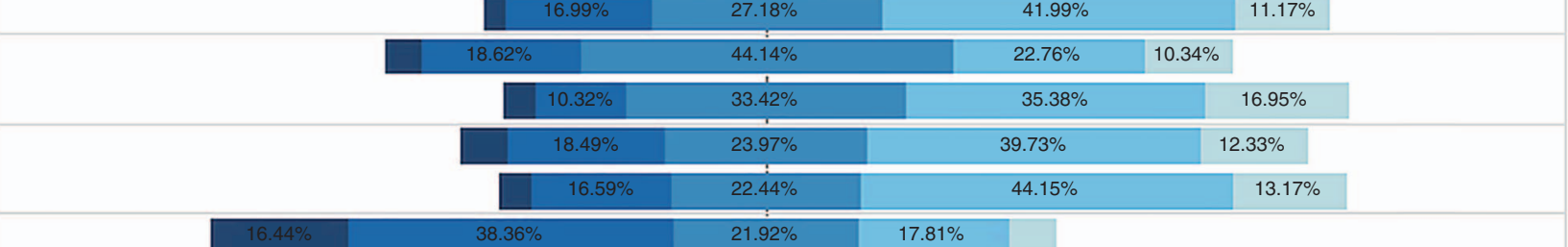

$30.10 \%$

$16.99 \%$

$-50$

Percentage

$54 \%$

$8.54 \%$

respondents
Rating

ery importan

Important

Neutral

Unimportant

Very Unimportan

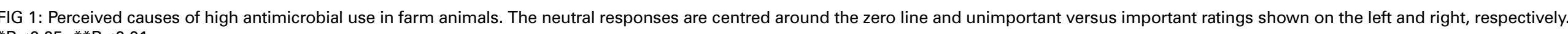
${ }^{*} \mathrm{P}<0.05 ;{ }^{* *} \mathrm{P}<0.01$ 
this as somewhat or very important, while almost half of the Dutch respondents regarded it as somewhat or very important.

Possible financial gains for veterinarians after prescribing were not believed to play an important role in high veterinary AMU by the majority of respondents, although in the Netherlands this was more pronounced compared with Flanders.

\section{Criteria for selection of antimicrobial treatment}

Both Flemish and Dutch respondents reported that personal experience, recommendations of veterinary experts/literature and the results of bacteriological culturing and sensitivity testing were the most important inputs to select a specific antimicrobial, although Dutch respondents had a significantly more pronounced view on the latter $(\mathrm{P}<0.01$, Fig 2$)$. Flemish respondents reported to rely the least on farmers' preferences in choosing an antimicrobial, while Dutch also cared little about pharmaceutical recommendations $(\mathrm{P}<0.01)$ and prices of antimicrobials $(\mathrm{P}<0.01)$. Formularies were reported to be considerably more important in the Netherlands compared with Flanders. Withdrawal time of the antibiotic was significantly more important to Flemish respondents in comparison to the Dutch $(\mathrm{P}<0.01$, Fig 2).

\section{Attitude of veterinarians towards antimicrobial reduction and the role of the veterinary pharmacy}

The majority of respondents from both countries believed that the possible veterinary contribution to AMR was worrisome; this belief was stronger among Dutch veterinarians (Fig 3). A great majority of respondents reported to have become more aware of the need to restrictively use antimicrobials and were aiming to reduce AMU in their practice as far as possible. Dutch respondents were on average in favour of the existing Dutch policy to halve veterinary AMU, while Flemish respondents were less supportive of the introduction of a similar policy in Flanders. The latter were significantly more afraid of negative consequences from halving veterinary AMU in terms of animal health and welfare issues compared with their Dutch counterparts. Flemish respondents reported to be significantly less reticent to prescribe antimicrobials to prevent or immediately treat a suspected bacterial infection compared with Dutch respondents. Respondents from both countries shared a comparable view on the current importance of the veterinary pharmacy for the viability of a veterinary practice (Fig 4). Flemish respondents were less optimistic about their ability to earn a decent income when pharmacy incomes would disappear compared with Dutch respondents. Conserving the veterinary pharmacy in the future was a strong motivator for all respondents to work on reducing AMU, but it was a significantly greater motivator for Flemish respondents $(\mathrm{P}<0.01)$

\section{Pressure to prescribe}

About one-third of the Flemish and of the Dutch respondents reported to never have felt a pressure from a farmer to prescribe antimicrobials against their own opposing opinion. A comparable proportion (31.9 per cent) of the Flemish respondents felt at least once in every two months forced to prescribe, while Dutch respondents (14.5 per cent) felt this pressure less often $(\mathrm{P}<0.01)$.

\section{Expected achievable reduction of AMU}

The achievable antimicrobial reduction as estimated by respondents in farm animals in 2015 compared with 2009 is shown in Fig 5. Dutch respondents were more optimistic on the achievable reduction of AMU in all animal species and especially in cattle and swine where the expectation was almost double that of Flemish respondents.

\section{Perceived contribution of several measures to antimicrobial reduction}

Respondents from both countries shared the opinion that strong reducing effects on AMU could be expected from improvements in housing and climate conditions for farm animals as well as from the strict control of infectious diseases and better implementation of biosecurity measures (Fig 6). Dutch respondents had a stronger belief in the positive effects of benchmarking of veterinary AMU $(\mathrm{P}<0.01)$ and improving the quality of animal feed $(\mathrm{P}<0.01)$. In both countries, it was believed that uncoupling prescribing and dispensing of antimicrobials by veterinarians would hardly have any effect on the reduction of AMU.

\section{Discussion}

In this study, the authors investigated the existing similarities and differences in opinions of farm animal veterinarians working in two neighbouring countries with comparable types of animal production systems (EUROSTAT 2015), but with a diverging policy towards the issue of AMU in veterinary medicine at the time of the study. Respondents from both countries endorsed the problem of extensive veterinary AMU as a risk for AMR development in humans and the necessity to reduce veterinary AMU. Most Dutch respondents supported the existing national policy to halve veterinary AMU. However, Flemish veterinarians were less supportive of such a policy as they were more afraid of negative consequences on animal health and welfare. Opinions on the effectiveness and necessity of several measures on reduction of AMU were quite comparable between the two countries. Respondents from both countries considered optimisation of housing and climate conditions, control of infectious animals and improvement in the level of biosecurity important measures in the reduction of AMU. Also differences were visible. Flemish respondents emphasised the need to increase biosecurity levels and to change farmers' mentality while the Dutch respondents saw greater potential in benchmarking AMU and improvements of feed quality.

\section{Limitations/reflections}

Despite efforts to increase the response rate by offering vouchers and sending reminders, the response rate could not be increased beyond 26 per cent and 40 per cent in both countries, which is comparable to or better than other questionnaire studies among veterinarians (Gunn and others 2008, Dean and others 2011, De Briyne and others 2013). In Belgium, post-academic training is mandatory for large animal veterinarians and assures a fairly complete email contact list of veterinarians (Nederlandstalige gewestelijke raad van de Orde der dierenartsen 2015). Non-responder analysis was difficult in Flanders. However, the data show that there was a great variety in respondents in terms of years of experience and time spent at different animal species. In the Netherlands, no response bias based on years of experience of the respondents or distribution of working time over animal species was found (Speksnijder and others 2015b). The low to medium response rates might have introduced some bias in the results as better informed veterinarians with a higher interest in the topic were probably more willing to share their support or, on the contrary, their discontent with current and potential policy measures. However, the authors could not think of any reason why this potential bias would influence the results in different directions in both countries, so the results at least suggest that there are differences in attitudes between veterinarians from the Netherlands and Flanders concerning this topic. Probably the difference in response rates in both countries in this study can be explained by the fact that every respondent in the Netherlands received an incentive, while in Flanders respondents only got a small chance to receive an incentive. In future studies, it might be worth considering giving all respondents an incentive to improve response rates. Also, communicating the importance of the survey and reminding respondents via diverse media might be beneficial to improve response rates.

At the moment of executing this study, a 32 per cent reduction in veterinary AMU was just reported in the Netherlands in the period 2009-2011, without major detrimental effects on animal health and productivity (Bondt and others 2012). This was obviously known to the Dutch respondents. Both Dutch farmers and veterinarians have thus personally experienced the 


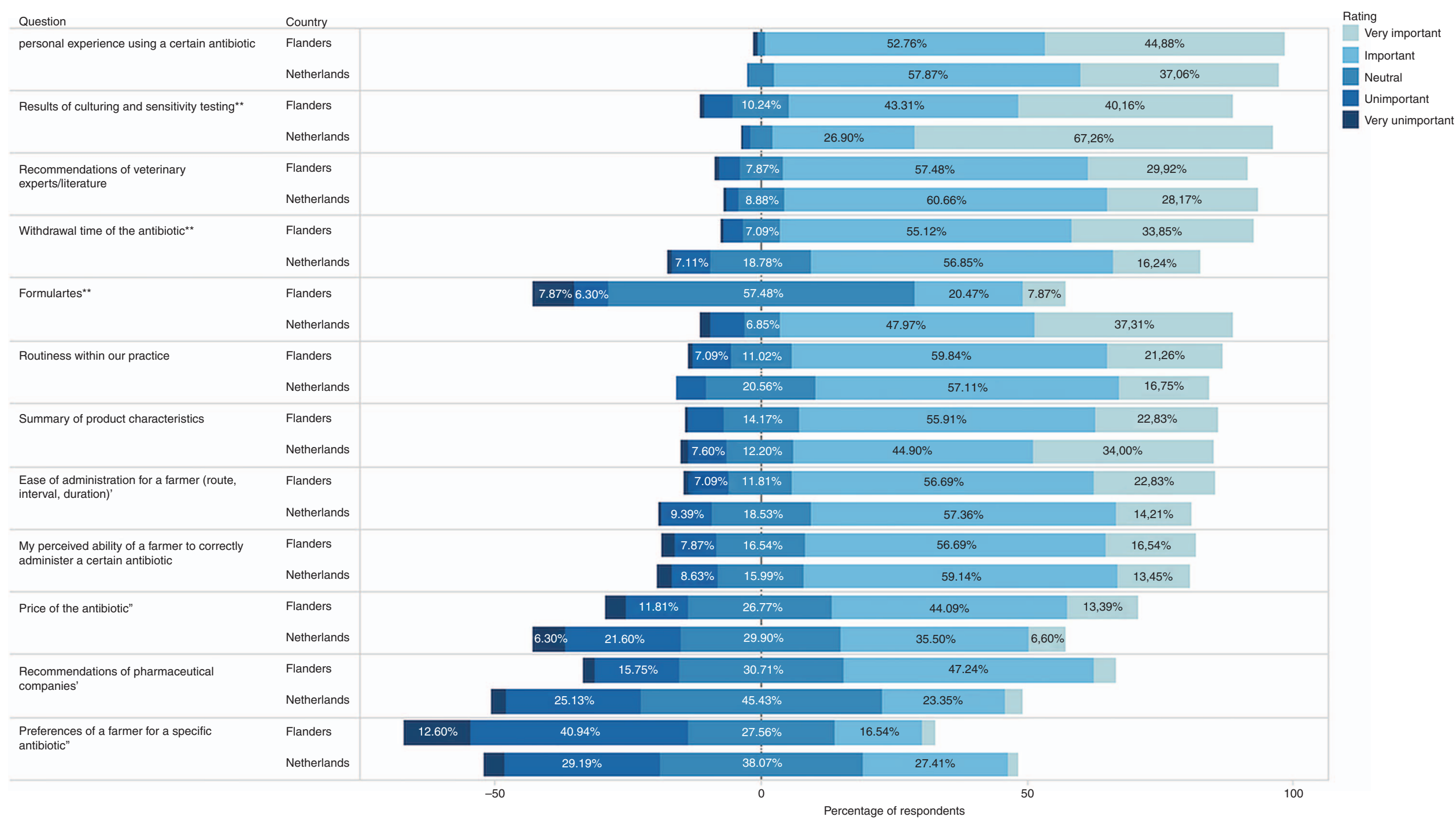

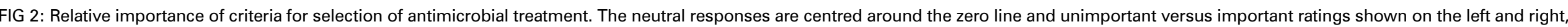
respectively. ${ }^{*} \mathrm{P}<0.05$; ${ }^{*} \mathrm{P}<0.01$ 
Question

Country

When $\mathrm{i}$ think $\mathrm{i}$ can prevent diseases with antibiotic treatment, i do not have difficulties

with prescribing*

Flanders

The possible contribution of veterinary antibiotic use to development of resistance in

Flanders

Last years i have become more aware of the

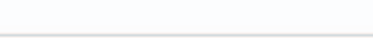

It is my goal to reduce antibiotic use in my

( would) support the policy to halve

Halving veterinary antibiotic use will be at the

expense of animal health and animal wel

Confronted with a probable bacterial

infection, i prefer to immediately sta

(1)

Netherlan

Netherlands

Flanders

Netherlands

Flanders

Netherlands

Flanders

Netherlands

Flanders

Netherlands

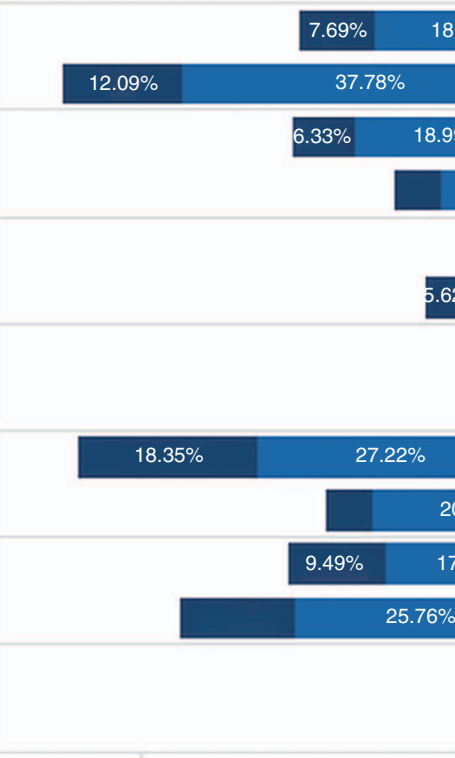

FIG 3: Attitudes of veterinary antimicrobial use. The neutral responses are centred around the zero line and unimportant versus important ratings shown on the left and right, respectively. ${ }^{*} \mathrm{P}<0.05$ ${ }^{* *} \mathrm{P}<0.01$ 

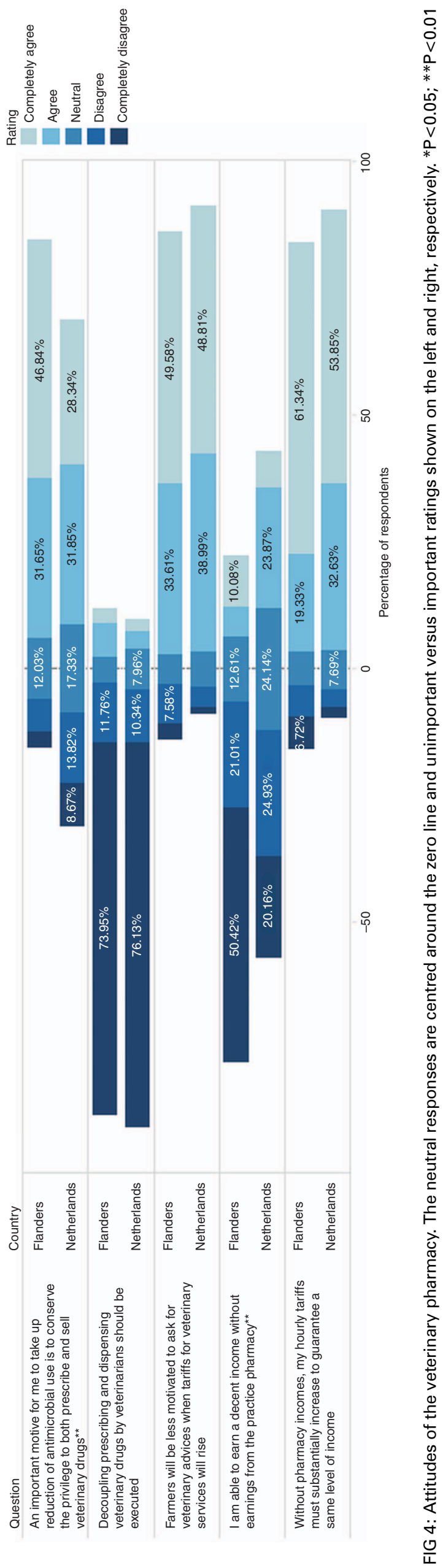

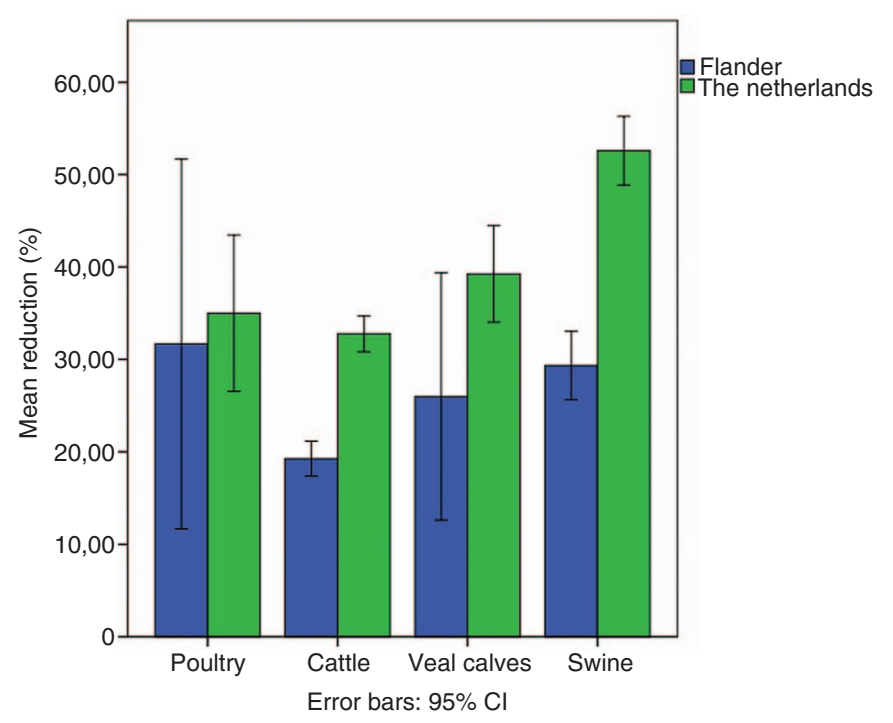

FIG 5: Perceived achievable veterinary reduction of antimicrobial use in 2015 compared with 2009 in percentages

results of this remarkable reduction in AMU, which could explain their rather positive attitudes towards reduction opportunities. Interestingly, the by Dutch respondents reported achievable reductions in AMU per sector were in fact achieved by the end of 2014, indicating the respondents were in 2012 already very able to indicate a realistic reduction level per sector (The Netherlands Veterinary Medicines Authority, 2015). Flemish respondents have up to now not yet experienced such a strong reduction themselves, which might explain their more sceptical opinion towards halving veterinary AMU. More than their Dutch counterparts, Flemish respondents in this study reported to have acquired an awareness in the last years to prescribe antimicrobials restrictively. The Dutch respondents probably had changed their attitudes already at an earlier stage as the public debate in the Netherlands about veterinary AMU started earlier than in Belgium. In 2014, also the Belgian sector has announced through the AMCRA their willingness to reduce AMU in farm animals with 50 per cent by 2020 (AMCRA 2014a, b). Benchmarking of veterinary antimicrobial prescribing and use, as is implemented in the Netherlands, will also be part of this plan and might be necessary as the reduction in veterinary AMU in Belgium until 2014 was relatively small (Dewulf and others 2015). It will be highly interesting to evaluate to what extent the setting of this strict quantitative goal influences the opinion of veterinarians in Flanders in the future.

Economic considerations are often mentioned as important barrier for specific disease-preventing strategies and farmers appear more worried about financial issues than about AMR (McEwen and Fedorka-Cray 2002, Visschers and others 2015). Flemish veterinarians were sensitised in optimising the level of biosecurity and taking overall preventive measures in several research projects (e.g. Ghent University (2010)) during the distribution of this questionnaire. This might have caused them to rank measures related to biosecurity as more important, a bias that should be taken into account when considering the conclusions.

The majority of the respondents felt unable to earn a decent income without their pharmacy incomes and respondents from both countries were relatively unanimous in their belief that decoupling the prescribing and selling of veterinary drugs, a measure that is often promoted by policymakers, will not greatly impact the level of AMU. An independent advisory body in the Netherlands also concluded in 2010 that decoupling as a single measure was not expected to contribute much to the desired reduction (Speksnijder and others 2015a, b). 


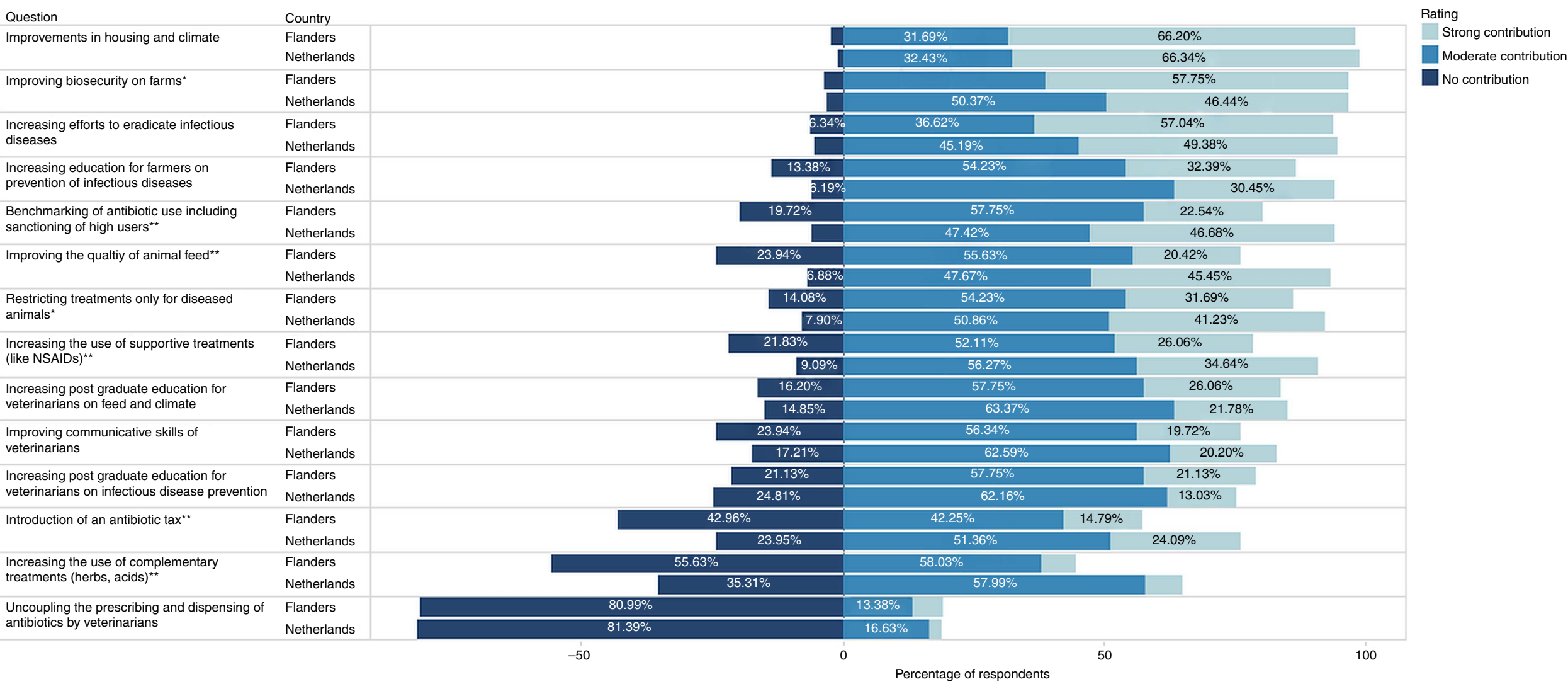

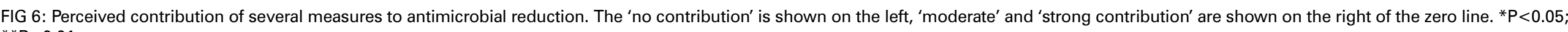
${ }^{*} \mathrm{P}<0.01$ 


\section{Comparison with existing literature}

The highly ranked possible causes of extensive AMU in farm animals in this study (suboptimal stable climate, lack of biosecurity, low immunity, economic considerations) are confirmed by many other authors (McEwen and Fedorka-Cray 2002, Brscic and others 2012, Laanen and others 2013). Flemish veterinarians in this study tend to link the reasons for high AMU more with farmers' mentality and lack of implementation of preventive measures, whereas Dutch respondents are more inclined towards specific animal problems such as insufficient immunity of young animals (which are supplied to raising farms) and economic considerations of farmers. Laanen and others (2014) showed that there still are biosecurity measures that are not being implemented in Belgium and that lack of knowledge and insufficient motivation is an important factor for Belgian farmers not to implement biosecurity and diseases prevention measures. Better explanation by veterinarians concerning costs and benefits of these measures would improve their motivation. In a recent study by Visschers and others (2015), Flemish pig farmers reported to receive less information from their veterinarians on prudent AMU, their risks and alternatives compared with some other European countries, suggesting a correlation between farmers' and veterinarians' attitude and behaviour in Flanders.

A recent study among pig experts in six European countries showed similar findings; improving the biosecurity level was ranked as a promising alternative for AMU, while improvements in feed quality received a lower score in Belgium compared with some of the other countries (Postma and others 2015). In Belgium, approximately 50 per cent of the finisher production is in the hands of feed companies (Instituut voor de Nationale Rekeningen 2009, 2015). Therefore, relatively more veterinarians are employed by feed companies, which might make it less accepted to comment on the quality of the feed (Snijders and others 2007, Instituut voor de Nationale Rekeningen 2009, 2015). Flemish respondents in this study reported a lower threshold to quickly apply antimicrobials to treat or prevent a suspected bacterial infection compared with Dutch veterinarians. Vandeweerd and others (2012), in a study among French-speaking Belgian veterinarians, also found the tendency of Belgian veterinarians to treat immediately when confronted with a disease. Flemish veterinarians in this study also reported to be more afraid of animal health and welfare impairments when a fixed level of antimicrobial usage reduction would be proposed. Finally, they reported the risk-averse mentality of farmers to be an important factor in AMU in farm animals; the use of antimicrobials is preferred by Flemish farmers above the risks of small production losses due to outbreaks of infectious diseases. This finding is confirmed by Visschers and others (2015). All these observations lead to the impression that Flemish veterinarians are more risk averse compared with their Dutch colleagues when it comes to antimicrobial prescribing. Grol and others (1990) and Deschepper and others (2008) concluded that compared with the Netherlands, Belgium is characterised by a higher level of uncertainty avoidance and power distance (indicating a greater hierarchical distance between doctor and patient), leading to higher antimicrobial prescribing in medical healthcare. Easily prescribing antimicrobials can be explained as a coping strategy for an uncertain diagnosis and to avoid a 'doctor does not know' situation, which might be perceived as undermining the status of the doctor or veterinarian as an expert (Hulscher and others 2010). In the Netherlands, due to the lower power distance, there probably is a higher tendency for deliberation between veterinarian and the farmer about the necessity for antimicrobial therapy, thereby lowering the chance for overestimating the demand of farmers for antimicrobial prescription. What also should be noted is the fact that attitudes of Dutch farmers regarding AMU recently have changed, probably resulting in a real lower demand for antimicrobials and a lower threshold for alternatives (Speksnijder and others 2015b).
Cultures cannot easily be changed. However, intensive international cooperation in the approach of the AMR issue and shared stewardship programmes as well as specific educational programmes might be helpful in slowly changing the culture of extensive AMU (Hulscher and others 2010). Acquired knowledge about best practices to reduce antimicrobials should extensively be shared between countries, not only at policy level, but also at grassroots levels. Dutch policymakers, veterinarians and farmers took special interests in Danish accomplishments on reduction of AMU in the last decade. In the same way, Flemish veterinarians can learn from the Dutch experience and adopt the best practices (Speksnijder and others 2015c).

The reported most important information sources for the selection of antimicrobial interventions in this study were personal experience, recommendations from experts and results of culturing/sensitivity testing. This highly substantiates the findings of De Briyne and others (2013), who indicated that personal experience and results of sensitivity testing were major criteria for the selection of antimicrobials by veterinarians. They also found that formularies/prescription guidelines were less important for Belgian veterinarians in their selection of an antimicrobial. During the study period, formularies were not yet available in Flanders. They were only introduced from 2014 onwards by the AMCRA. The fact that veterinarians were not yet too enthusiastic about formularies could be because of the fact that their benefits were still unknown to them. Another explanation can be the great emphasis veterinarians place on personal experience. Vandeweerd and others (2012) describe the reported importance of personal experience in clinical decision-making of veterinarians in Belgium in relation to evidence-based information sources. These authors expressed a need to incorporate scientific evidence into clinical practice through mandatory continuing education or other tools that can be applied to veterinarians' busy daily practice like guidelines.

\section{Conclusions}

The assessed attitudes of veterinarians between the Netherlands and Flanders towards AMU and AMR showed some marked similarities and differences. Cultural differences (level of risk averseness, characteristics of the veterinarian-client relationship) in combination with diverging policies towards veterinary AMU in Belgium and the Netherlands seem to be the basis for these differences. The Dutch approach, with very strict policy measures, seems to be effective in reducing AMU and probably also in changing attitudes of veterinarians towards AMU. These results can be important to convince Flemish counterparts of the feasibility of drastic reduction in veterinary AMU without clear detrimental effects.

\section{Twitter Follow Merel Postma at @MerelPostma}

\section{Acknowledgements}

The veterinarians are acknowledged for their participation in this study.

\section{Contributors MP and DCS contributed equally to the article.}

Correction notice This article has been corrected since it was published Online First. The author's name D.A.C. Jaarsma has been updated to correctly read A.D.C. Jaarsma.

Funding This study was done in the Netherlands and funded by the Netherlands Organization for Health Research and Development (ZonMW), project no. 205100009.

\section{References}

AARESTRUP, F. M., WEGENER, H. C. \& COLLIGNON, P. (2008) Resistance in bacteria of the food chain: Epidemiology and control strategies. Expert Review of Anti-infective Therapy 6, 733-750

AMCRA (2014a) Center of Expertise on Antimicrobial Consumption and Resistance in Animals (AMCRA). www.amcra.be Accessed June 10 2014, Access 2014a

AMCRA (2014b) Visie 2020 - Center of Expertise on Antimicrobial Consumption and Resistance in Animals (AMCRA). http://amcra.be/sites/default/files/ 
bestanden/AMCRA\%202020\%20finaal_NL\%20-\%20definitief.pdf Accessed July 9 2014, Access 2014b

BONDT, N., PUISTER, L., LAN, G., VAN DER VEEN, H., BERGEVOET, R. DOUMA, B., VAN VLIET, A. \& WEHLING, K. (2012) Trends in veterinary antibiotic use in The Netherlands 2004-2012. http://www.wageningenur.nl/web/ file? uuid=dce8ef49-b52b-4fd3-bce2-54a4fdda98b2 \&owner=cbe0eb4c-8e83-479da9da-f407b46ea372

BRSCIC, M., LERUSTE, H., HEUTINCK, L. F. M., BOKKERS, E. A. M., WOLTHUIS-FILLERUP, M., STOCKHOFE, N., GOTTARDO, F., LENSINK, B. J., COZZI, G. \& VAN REENEN, C. G. (2012) Prevalence of respiratory disorders in veal calves and potential risk factors. Journal of Dairy Science 95, 2753-2764

COENEN, S., MULLER, A., ADRIAENSSENS, N., VANKERCKHOVEN, V. HENDRICKX, E. \& GOOSSENS, H. (2009) European surveillance of antimicrobial consumption (ESAC): Outpatient parenteral antibiotic treatment in Europe. Journal of Antimicrobial Chemotherapy 64, 200-205

COENEN, S., WELSCHEN, I., ROYEN, P. V., KUYVENHOVEN, M. M., DENEKENS, J. \& VERHEIJ, T. J. M. (2004) Management of acute cough: Comparisons between Belgian and Dutch GPs. European Journal of General Practice 10, 152-156

COLLIGNON, P., POWERS, J. H., CHILLER, T. M., AIDARA-KANE, A. \& AARESTRUP, F. M. (2009) World health organization ranking of antimicrobials accoring to their importance in human medicine: A critical step for developing risk management strategies for the use of antimicrobials in food production animals. Clinical Infectious Diseases, 49, 132-141

DE BRIYNE, N., ATKINSON, J., POKLUDOVÁ, L., BORRIELLO, S. P. \& PRICE, S. (2013) Factors influencing antibiotic prescribing habits and use of sensitivity testing amongst veterinarians in Europe. Veterinary Record 173, 475

DEAN, W. R., MCINTOSH, W. A., SCOTT, H. M. \& BARLING, K. S. (2011) The role of trust and moral obligation in beef cattle feed-lot veterinarians' contingen adoption of antibiotic metaphylaxis recommendations. International Journal of Sociology of Agriculture and Food 18, 104-120

DESCHEPPER, R., GRIGORYAN, L., LUNDBORG, C. S., HOFSTEDE, G. COHEN, J., KELEN, G. V., DELIENS, L. \& HAAIJER-RUSKAMP, F. M. (2008) Are cultural dimensions relevant for explaining cross-national differences in antibiotic use in Europe? BioMed Central Health Services Research 8, 123

DEWULF, J., B., H. \& MINNE, D. (2014) Belgian veterinary surveillance of antimicrobial consumption: National Consumption Report 2013. http://www. amcra.be/sites/default/files/bestanden/belvetsac\%20report\%202013 4.pdf

DEWULF, J., HOET, B. \& MINNE, D. (2015) Belgian veterinary surveillance of antimicrobial consumption: National Consumption Report 2014. In Ed BelVet-SAC. Merelbeke, Belgium. http://www.belvetsac.ugent.be/pages/home/ BelvetSAC_report_2014\%20finaal.pdf

ESVAC (2012) Sales of veterinary antimicrobial agents in 19 EU/EEA countries in 2010 - Second ESVAC report. http://www.ema.europa.eu/docs/en_GB/document library/Report/2012/10/WC500133532.pdf European Medicines, Agency

EUROSTAT (2015) Statistics Explained - Agri-environmental indicator - Livestock patterns. http://ec.europa.eu/eurostat/statistics-explained/index.php/Agri-environmenta indicator - livestock patterns Access 2015

GHENT UNIVERSITY (2010) Project REDuction AntiBiotics. http://www abcheck.ugent.be/v2/redab/ Access 2010

GIBBONS, J., BOLAND, F, BUCKLEY, J. F, BUTLER, F, EGAN, J., FANNING, S, MARKEY, B. K. \& LEONARD, F. C. (2013) Influences on antimicrobial prescribing behaviour of veterinary practitioners in cattle practice in Ireland. Veterinary Record 172, 14-14

GROL, R., WHITFIELD, M., DE MAESENEER, J. \& MOKKINK, H. (1990) Attitudes to risk taking in medical decision making among British, Dutch and Belgian general practitioners. The British Journal of General Practice 40, 134

GUNN, G. J., HEFFERNAN, C., HALL, M., MCLEOD, A. \& HOVI, M. (2008) Measuring and comparing constraints to improved biosecurity amongst GB farmers, veterinarians and the auxiliary industries. Preventive Veterinary Medicine 84, 310-323

HULSCHER, M., VAN DER MEER, J. \& GROL, R. (2010) Antibiotic use: how to improve it? International Journal of Medical Microbiology 300, 351-356

INSTITUUT VOOR DE NATIONALE REKENINGEN (2009) Prijzen, kosten en redabiliteit in de varkenskolom. In Ed FOD ECONOMIE - K.M.O.Brussels, Belgium: MIDDENSTAND EN ENERGIE

INSTITUUT VOOR DE NATIONALE REKENINGEN (2015) Actualisatie van de studie over de varkenskolom. In Ed K. M. O. FOD ECONOMIE. Brussels, Belgium: MIDDENSTAND EN ENERGIE
LAANEN, M., MAES, D., HENDRIKSEN, C., GELAUDE, P., DE VLIEGHER, S., ROSSEEL, Y. \& DEWULF, J. (2014) Pig, cattle and poultry farmers with a known interest in research have comparable perspectives on disease prevention and on-farm biosecurity. Preventive Veterinary Medicine 115, 1-9

LAANEN, M., PERSOONS, D., RIBBENS, S., DE JONG, E., CALLENS, B. STRUBBE, M., MAES, D. \& DEWULF, J. (2013) Relationship between biosecurity and production/antimicrobial treatment characteristics in pig herds. The Veterinary Journal 198, 508-512

MCEWEN, S. A. (2006) Antibiotic use in animal agriculture: What have we learned and where are we going? Animal Biotechnology 17, 239-250

MCEWEN, S. A. \& FEDORKA-CRAY, P. J. (2002) Antimicrobial use and resistance in animals. Clinical Infectious Diseases 34, S93-S106

MORLEY, P. S., APLEY, M. D., BESSER, T. E., BURNEY, D. P., FEDORKA-CRAY, P. J., PAPICH, M. G., TRAUB-DARGATZ, J. L. \& WEESE, J. S. (2005) Antimicrobial drug use in veterinary medicine. Journal of Veterinary Internal Medicine 19 617-629

NEDERLANDSTALIGE GEWESTELIJKE RAAD VAN DE ORDE DER DIERENARTSEN (2015) Code der plichtenleer. HOGE RAAD VAN DE ORDE DER DIERENARTSEN

POSTMA, M., STÄRK, K. D. C., SJÖLUND, M., BACKHANS, A., BEILAGE, E. G., LÖSKEN, S., BELLOC, C., COLLINEAU, L., ITEN, D., VISSCHERS, V., NIELSEN, E. O. \& DEWULF, J. (2015) Alternatives to the use of antimicrobial agents in pig production: A multi-country expert-ranking of perceived effectiveness, feasibility and return on investment. Preventive Veterinary Medicine 118, 457-466

PRESCOTT, J. F. (2008) Antimicrobial use in food and companion animals. Animal Health Research Reviews 9, 127-133

SNIJDERS, H., VROLIJK, H. \& JACOBS, D. (2007) De economische kracht van agrofood in Nederland. In Eds T. BAKKER, M. GROOTHEIM, R. PARS, L. DVORTSIN. pp 145-147

SPEKSNIJDER, D C. JAARSMA, A. D C., VAN DER GUGTEN, A. C., VERHEIJ, T. J. M. \& WAGENAAR, J. A. (2015a) Determinants associated with veterinary antimicrobial prescribing in farm animals in the Netherlands: a qualitative study. Zoonoses and Public Health 62, 39-51

SPEKSNIJDER, D. C., JAARSMA, D. A. C., VERHEIJ, T. J. M. \& WAGENAAR, J. A (2015b) Attitudes and perceptions of Dutch veterinarians on their role in the reduction of antimicrobial use in farm animals. Preventive Veterinary Medicine $\mathbf{1 2 1}$ 365-373

SPEKSNIJDER, D. C., MEVIUS, D. J., BRUSCHKE, C. J. M. \& WAGENAAR, J. A (2015c) Reduction of veterinary antimicrobial use in the Netherlands. The Dutch Success Model. Zoonoses and Public Health 62, 79-87

VAN BOECKEL, T. P., BROWER, C., GILBERT, M., GRENFELL, B. T., LEVIN, S. A ROBINSON, T. P., TEILLANT, A. \& LAXMINARAYAN, R. (2015) Global trends in antimicrobial use in food animals. Proceedings of the National Academy of Sciences 112, 5649-5654

VAN GEIJLSWIJK, I., HEEDERIK, D., WAGENAAR, J. A., MOUTON, J. W. JACOBS, J., DORADO GARCIA, A., MEVIUS, D. J., DIERIKX, C., VELDMAN, K. T., WIT, B. \& VAN PELT, W. (2015) MARAN 2015 - Monitoring of Antimicrobial Resistance and Antibiotic Usage in Animals in the Netherlands in 2014. In Eds D. J. MEVIUS, C. M. DIERIKX, K. T. VELDMAN, B. WIT, W. VAN PELT, D. HEEDERIK. Lelystad, the Netherlands: Central Veterinary Institute of Wageningen University and Research Centre pp, 119-190

VANDEWEERD, J.-M., VANDEWEERD, S., GUSTIN, C., KEESEMAECKER, G., CAMBIER, C., CLEGG, P., SAEGERMAN, C., REDA, A., PERRENOUD, P. \& GUSTIN, P. (2012) Understanding veterinary practitioners' decision-making process: implications for veterinary medical education. Journal of Veterinary Medical Education 39, 142-151

VISSCHERS, V. H. M., BACKHANS, A., COLLINEAU, L., ITEN, D., LOESKEN, S, POSTMA, M., BELLOC, C., DEWULF, J., EMANUELSON, U., BEILAGE, E. G., SIEGRIST, M., SJÖLUND, M. \& STÄRK, K. D. C. (2015) Perceptions of antimicrobial usage, antimicrobial resistance and policy measures to reduce antimicrobial usage in convenient samples of Belgian, French, German, Swedish and Swiss pig farmers. Preventive Veterinary Medicine 119, 10-20 